\title{
The effects of $\boldsymbol{A}$. pyogenes on endometrial function in vitro, and on uterine and ovarian function in vivo
}

\author{
A.N.A. Miller ${ }^{1}$, E.J. Williams ${ }^{1}$, K. Sibley ${ }^{1}$, S. Herath ${ }^{1}$, E.A. Lane ${ }^{1}$, J. Fishwick ${ }^{1}$, D.M. Nash ${ }^{1}$, \\ A.N. Rycroft ${ }^{2}$, H. Dobson ${ }^{3}$, C.E. Bryant ${ }^{4}$, and I.M. Sheldon ${ }^{1, a}$ \\ ${ }^{1}$ Department of Veterinary Clinical Sciences, Royal Veterinary College, Royal College Street, \\ London, NW1 OTU, UK. \\ 2 Department of Pathology and Infectious Diseases, Royal Veterinary College, Royal College \\ Street, London, NW1 0TU, UK. \\ ${ }^{3}$ Department of Veterinary Clinical Science and Animal Husbandry, Faculty of Veterinary \\ Science, University of Liverpool, Leahurst, Neston, CH64 7TE. \\ ${ }^{4}$ Department of Veterinary Medicine, University of Cambridge, Madingley Road, Cambridge, CB3 \\ OES, UK.
}

\begin{abstract}
Uterine bacterial infection after parturition causes endometritis, perturbs ovarian function and leads to infertility in cattle. Although endometritis is caused by mixed infections, endometrial pathology is associated with the presence of Arcanobacterium pyogenes. The aims of the present study were to determine the effects of $A$. pyogenes on endometrial function in vitro, and on uterine and ovarian function in vivo. Heat-killed A. pyogenes did not affect the production of prostaglandin $\mathrm{F}_{2 a}(\mathrm{PGF})$ or prostaglandin $\mathrm{E}_{2}(\mathrm{PGE})$ from endometrial explants, or purified populations of endometrial epithelial or stromal cells. However, the explants produced more PGF and PGE than controls when treated with a bacteria-free filtrate (BFF) cultured from $A$. pyogenes. Similarly, BFF stimulated PGF and PGE production by epithelial and stromal cells, respectively. So, BFF or control PBS was infused into the uterus of heifers ( $n=7$ per group) for 8 days, starting the day after estrus. Emergence of the follicle wave, dominant follicle or corpus luteum diameter, and peripheral plasma FSH, LH, estradiol, progesterone, PGFM, or acute phase protein concentrations were unaffected by the BFF infusion. In the live animal it is likely that the intact uterine mucosa limits the exposure of the endometrial cells to the exotoxin of $A$.pyogenes, whereas the cells are readily exposed to the toxin in vitro.
\end{abstract}

\section{Keywords}

Inflammation; postpartum infection; reproductive immunology

\section{Introduction}

\begin{abstract}
Bacterial contamination of the uterine lumen after parturition is common in dairy cattle, and uterine disease is an important cause of infertility. Within 2 weeks of parturition, $40 \%$ of cows develop metritis and infection persists in $15 \%$ of animals as endometritis $(1,2)$. In typical studies of cows with endometritis compared with normal animals, conception rates
\end{abstract}

\footnotetext{
Address correspondence and reprint requests to I.M. Sheldon, Department of Veterinary Clinical Sciences, Royal Veterinary College, Royal College Street, London, NW1 0TU, UK. Email address: sheldon@ @rvc.ac.uk. ${ }^{a}$ Corresponding author. Tel: +44-207-4685246; Fax: +44-0207-3882342; E-mail: sheldon@ rvc.ac.uk (I.M. Sheldon).
} 
are approximately $20 \%$ lower, the median calving to conception interval is 30 days longer and there are $3 \%$ more animals culled for failure to conceive $(3,4)$. Furthermore, cows with a purulent cervical discharge have lower submission rates (5). In addition to the effects on reproduction, uterine disease causes pain, suffering and a systemic inflammatory response. For example, peripheral plasma concentrations of acute phase proteins such as haptoglobin or $a_{1}$-acid glycoprotein (AGP) are increased in animals with uterine bacterial infection (6). Furthermore, after parturition plasma concentrations of the prostaglandin $\mathrm{F}_{2 a}$ metabolite (13,14-dihydro-15-keto-PGF ${ }_{2 a}$; PGFM) are increased, which likely reflect uterine tissue damage and infection $(7,8)$.

The infertility associated with uterine disease is correlated with endometrial trauma and inflammation $(9,10)$. However, there is also evidence of wider effects on the reproductive axis including persistence of the corpus luteum and failure of ovulation (11). The underlying mechanism for disruption of luteolysis is probably associated with bacteria stimulating production of more prostaglandin $\mathrm{E}_{2}$ (PGE) than prostaglandin $\mathrm{F}_{2 a}$ (PGF) from the endometrium (12). In addition, uterine disease suppresses the growth of ovarian dominant follicles and perturbs their function, as determined by lower peripheral plasma estradiol concentrations (2). Finally, bacteria, or their pathogen associated molecules, within the uterine lumen suppress the secretion of luteinising hormone (LH) from the pituitary $(13,14)$; although the secretion of follicle stimulating hormone (FSH) appears to be unaffected (2).

In the postpartum cow, the pathogenic bacteria that are frequently isolated from cases of endometritis are Escherichia coli and Arcanobacterium pyogenes $(15,16)$. The effects of $E$. coli or its pathogen-associated molecule, lipopolysaccharide (LPS), on reproductive function have been widely investigated (12-14). However, severe endometritis is particularly associated with the presence of $A$. pyogenes $(10,15)$. A. pyogenes is a gram-positive aerobic bacillus that secretes its virulence factors rather than interacting directly with host cells (17). When infused into the uterine lumen of cows, a bacteria-free filtrate of $A$. pyogenes stimulates an immune response, as determined by an influx of neutrophils into the uterine lumen (18). However, the effects of $A$. pyogenes on uterine and ovarian function are less clear. The aims of the present study were to determine the effects of heat-killed A. pyogenes and a bacteria-free filtrate (BFF) on endometrial function in vitro, and on uterine and ovarian function in vivo.

\section{Materials and Methods}

\section{Preparation of heat-killed A. pyogenes and a bacteria-free filtrate}

A pathogenic strain of $A$. pyogenes was isolated from a postpartum cow showing clinical signs of endometritis subsequent to an episode of metritis with pyrexia (16). Swabs from the clinical case were cultured on sheep blood agar plates (Oxoid, Hants, UK) at $37^{\circ} \mathrm{C}$ for $48 \mathrm{~h}$ in an aerobic environment and preserved in semi-skimmed milk with $10 \%$ glycerol at $-80^{\circ} \mathrm{C}$. A. pyogenes was cultured from this bacterial stock on sheep blood agar plates and incubated at $37^{\circ} \mathrm{C}$ for $48 \mathrm{~h}$. Colonies were sub-cultured in $600 \mathrm{~mL}$ Brain Heart Infusion broth (BHI; Oxoid) supplemented with 5\% heat-inactivated foetal bovine serum (FBS; PAA, Somerset, UK) at $37^{\circ} \mathrm{C}$ for $48 \mathrm{~h}$. The purity of the $A$. pyogenes broth and number of CFU/ml was determined by streaking $50 \mu \mathrm{l}$ onto sheep blood agar plates that were incubated for $48 \mathrm{~h}$. Heat-killed $A$. pyogenes (HKAP) was prepared by heating half the $A$. pyogenes broth in BHI to $121^{\circ} \mathrm{C}$ for $15 \mathrm{~min}$, followed by centrifuging at $12,000 \times \mathrm{g}$ for 12 minutes at $4^{\circ} \mathrm{C}$. The supernatant was discarded and the pellet washed three times with ice-cold PBS; the bacteria were re-suspended in PBS and the HKAP stored at $-20^{\circ} \mathrm{C}$. The bacteria-free filtrate (BFF) was prepared by centrifugation of the remaining $A$. pyogenes broth at $12,000 \times \mathrm{g}$ for $12 \mathrm{~min}$ at $4^{\circ} \mathrm{C}$. The supernatant was filtered through a $0.45 \mu \mathrm{m}$ durapore Millex-HV low proteinbinding filter (Millipore, Billerica, USA) and the BFF stored at $-80^{\circ} \mathrm{C}$. 


\section{Endometrial explant and cell cultures}

Uteri with no gross evidence of genital disease were collected from post-pubertal nonpregnant cattle at an abattoir immediately after slaughter and transported to the laboratory on ice. The physiological stage of the reproductive cycle for each genital tract was determined by observation of the ovarian morphology (19). Genital tracts with an ovarian Stage II corpus luteum were used because animals in the luteal phase are most susceptible to disease (20).

Tissue explants were established as previously described (12). Briefly, the endometrium was cut into strips and placed into RPMI-1640 medium (Sigma) supplemented with $50 \mathrm{IU} / \mathrm{mL}$ of penicillin, $50 \mu \mathrm{g} / \mathrm{mL}$ of streptomycin and $2.5 \mu \mathrm{g} / \mathrm{mL}$ of Amphotericin B (Sigma), working under sterile conditions. The strips were then chopped into $1 \mathrm{~mm}^{3}$ pieces using a mechanical chopper (McIIwian Laboratory Engineering, UK) and $50 \mathrm{mg}$ of this tissue transferred onto metal grids in 6 well plates (Helena Biosciences, Switzerland) containing $4.25 \mathrm{~mL}$ of supplemented medium. The tissue explants were incubated at $37^{\circ} \mathrm{C}, 5 \% \mathrm{CO}_{2}$ in air, in a humidified incubator. After $24 \mathrm{~h}$, the supernatants were discarded and replaced with 4.25 $\mathrm{mL}$ media containing $100 \mathrm{nM}$ oxytocin (Bachem) and $100 \mu \mathrm{M}$ aracadonic acid (Sigma) as a positive control to confirm physiological function, HKAP (10 to $10^{5} / \mathrm{mL}$ ), BHI (2 to $28 \% \mathrm{v} /$ v) as a negative control for the vehicle containing BFF, BFF (equivalent to $0.4 \times 10^{9}$ to 3.0 $\times 10^{9} \mathrm{CFU} / \mathrm{mL}$ ), or $1 \mu \mathrm{g}$ E. coli O55:B5 LPS (Sigma) as a positive control to confirm the uterine cells were capable of a pathophysiological response. The concentrations of HKAP and LPS were based on those used for heat-killed E. coli and LPS previously (12). Each experiment was performed in triplicate and repeated at least 3 times using explants established from separate animals. The supernatants were collected $24 \mathrm{~h}$ after treatment and stored at $-20^{\circ} \mathrm{C}$ until analysed for prostaglandin concentrations.

For cell isolation, endometrial tissue was processed as previously described (12). Briefly, tissue was digested in sterile filtered digestive solution containing $50 \mathrm{mg}$ trypsin III (Roche, Lewes, UK), $50 \mathrm{mg}$ collagenase II (Sigma), $100 \mathrm{mg}$ BSA (Sigma), and $10 \mathrm{mg}$ DNase I (Sigma) in $100 \mathrm{~mL}$ HBSS in a shaking water bath at $37^{\circ} \mathrm{C}$ for $1.5 \mathrm{~h}$. After incubation, the cell suspension was filtered through a $40 \mu \mathrm{m}$ mesh (Fisher Scientific, Loughborough, UK) to remove undigested material, and the filtrate was resuspended in a HBSS washing medium containing $10 \%$ fetal bovine serum (FBS; Sigma) and $3 \mu \mathrm{g} / \mathrm{mL}$ trypsin inhibitor (Sigma). The suspension was centrifuged at $100 \times g$ for $10 \mathrm{~min}$ and, after two further washes, the cells were resuspended in RPMI 1640 supplemented with $10 \%$ FBS, $50 \mathrm{IU} / \mathrm{mL}$ penicillin, 50 $\mu \mathrm{g} / \mathrm{mL}$ streptomycin, and $2.5 \mu \mathrm{g} / \mathrm{mL}$ amphotericin B. The cells were plated in 24 well plates at a density of $1 \times 10^{5}$ cells in $2 \mathrm{~mL}$ supplemented medium. To obtain separate stromal and epithelial cell populations, the cell suspension was removed $18 \mathrm{~h}$ after plating, which allowed selective attachment of stromal cells. The removed cell suspension was then plated in a 24 well plate and incubated to allow epithelial cells to adhere. Stromal and epithelial cell purity was greater than $95 \%$ determined by light microscopy and the production of prostaglandins $\mathrm{E}_{2}$ and $\mathrm{F}_{2 \mathrm{a}}(21)$. All cultures were maintained at $37^{\circ} \mathrm{C}, 5 \% \mathrm{CO}_{2}$ in air, in a humidified incubator. The culture media was changed every $48 \mathrm{~h}$ until the cells reached confluence, and then treated with $100 \mathrm{nM}$ oxytocin (Bachem) and $100 \mu \mathrm{M}$ aracadonic acid (Sigma) as a positive control to confirm physiological function, BFF (equivalent to $0.8 \times 10^{9}$ or $1.6 \times 10^{9} \mathrm{CFU} / \mathrm{mL}$ ) or $1 \mu \mathrm{g}$ E. coli O55:B5 LPS as a positive control for a pathophysiological response. Each experiment was performed in triplicate and repeated at least 3 times using cells from separate animals. The supernatants were collected $24 \mathrm{~h}$ after treatment and stored at $-20^{\circ} \mathrm{C}$ until analysed for prostaglandin concentrations. 


\section{Prostaglandin radioimmunoassay}

Culture supernatants were analyzed for prostaglandin $E_{2}$ (PGE) and prostaglandin $F_{2 a}$ (PGF) by radioimmuoassay as previously described (22). Samples were diluted in $0.05 \mathrm{M}$ Tris buffer containing $0.1 \%$ gelatin and $0.01 \%$ sodium azide. Standards and tritiated tracers for the prostaglandins were purchased from Sigma and Amersham International PLC (Amersham, Little Chalfont, UK), respectively. The antisera were a generous gift from Prof. N. L. Poyser (University of Edinburgh, UK) and their cross-reactivities were: PGF antiserum, 0.54\% with PGE; PGE antiserum, $0.47 \%$ with PGF (23). The limits of detection for PGE and PGF were $2 \mathrm{pg} /$ tube and $1 \mathrm{pg} /$ tube, respectively. The intra- and inter-assay coefficients of variation were 4.4 and $7.8 \%$ for PGE, and 5.1 and $9.7 \%$ for PGF, respectively.

\section{In vivo experiment}

Seven nulliparous Holstein heifers aged between 18 to 20 months were assigned to control or BFF infusion in a crossover design. The animals received ad lib grass hay and $2 \mathrm{Kg} / \mathrm{head}$ concentrates twice daily (Growergrain Nuts, BOCM Pauls Ltd Ipswich), and were housed on straw in a naturally ventilated shed. No antimicrobial treatments were administered to heifers during the experiment. All procedures were carried out under Home Office authorisation in compliance with the Animals (Scientific Procedures) Act 1986 and ethical approval was granted from the Royal Veterinary College Ethical Review Committee.

Estrus was synchronised by administration of two intramuscular injections of a PGF analogue, cloprostenol (Estrumate, Schering-Plough Animal Health, Welwyn Garden City, UK) 11 days apart. The first injection $\left(\mathrm{PG}_{1}\right)$ ensured that a functional corpus luteum (CL) was present after 11 days. The second injection $\left(\mathrm{PG}_{2}\right)$ induced luteolysis of this CL to initiate ovulation, which was followed by a new wave of follicle growth and CL formation. Administration of a third prostaglandin injection $\left(\mathrm{PG}_{3}\right) 7$ days after first observation of standing estrus induced luteolysis of the newly formed $\mathrm{CL}$ and subsequent ovulation of the expected dominant follicle. To confirm the sterility of uteri for heifers before treatments were administered, a transcervical-guarded swab was collected from the uterine body of each animal, before $\mathrm{PG}_{1}$ was administered using a previously validated method (2). Each swab was placed in Stuart Transport Medium (Unipath, Basingstoke, UK), cultured aerobically and anaerobically, and bacteria identified using standard tests (2). In every case, the swabs were negative for pathogenic organisms.

Heifers were observed for signs of estrus for 30 min every $3 \mathrm{~h}$ for 3 days following the $\mathrm{PG}_{2}$ injection. The onset of the estrous cycle was defined as the first time a heifer stood to be mounted by another heifer and this time was designated as Day 0 . The stage of estrous cycle, and luteolysis after $\mathrm{PG}_{2}$ was confirmed by measuring progesterone concentrations in peripheral plasma and ultrasound examination. Starting $24 \mathrm{~h}$ (designated Day 1) after first standing estrus was observed, the animals were randomly assigned to infusion of $10 \mathrm{~mL}$ BFF (equivalent to $1.6 \times 10^{10} \mathrm{CFU} / \mathrm{mL}$ ) or control infusion of $10 \mathrm{~mL}$ sterile PBS (Sigma), administered every $6 \mathrm{~h}$ for 9 days. The animals were monitored for signs of illness and the rectal temperature measured every $6 \mathrm{~h}$ for 9 days. Following a rest period of 21 days, all animals were subjected to the same protocol, but assigned to the alternate treatment group.

\section{Ultrasound examination}

To monitor ovarian function, transrectal ultrasonography using a 7.5 MHz linear array probe and a Honda HS-Transrectal 2000 machine (Honda Electronics, Aichi, Japan) was conducted every $12 \mathrm{~h}$ from the day before $\mathrm{PG}_{2}$ administration for 14 days. Ovarian follicles were defined as non-echogenic black structures with clear demarcation between the follicular wall and stroma, whilst the CL was defined as an echogenic, grainy structure with 
or without a non-echogenic lacuna. The diameter of follicles and CL were determined using the internal callipers of the ultrasonography machine by measuring the two dimensions of each structure at $90^{\circ}$ angle and recording the average value. Ovarian follicles $>4 \mathrm{~mm}$ in diameter present in each ovary were identified, measured and recorded on an ovarian map. The emergence of a follicular wave was defined by the growth of a cohort of at least 2 follicles $>4 \mathrm{~mm}$ internal diameter and a dominant follicle was defined by an internal diameter $>8.5 \mathrm{~mm}$ in the absence of other growing follicles. The time of ovulation was retrospectively assigned as the day on which the dominant follicle disappeared from the ovary, if a CL subsequently developed in its place.

\section{Blood Sampling}

Blood samples were collected from the jugular vein into evacuated heparinised or plain tubes (BD Vacutainer Systems, Plymouth, UK). Blood samples were collected following administration of $\mathrm{PG}_{2}$ every $3 \mathrm{~h}$ for six days, every $12 \mathrm{~h}$ for five days and finally every $3 \mathrm{~h}$ until the end of the study. Heparinised tubes were transported on ice and plasma separated within $1 \mathrm{~h}$ of collection by centrifugation at $1,600 \times \mathrm{g}$ for $10 \mathrm{~min}$ at $4^{\circ} \mathrm{C}$. Blood samples collected in plain tubes were incubated at room temperature for at least $1 \mathrm{~h}$ then centrifuged at $1,600 \times \mathrm{g}$ for $10 \mathrm{~min}$ at $4^{\circ} \mathrm{C}$ to isolate serum. Isolated plasma and serum were stored at $-20^{\circ} \mathrm{C}$ until assayed.

\section{Hormone analysis}

Once daily peripheral plasma progesterone concentrations were measured in duplicate using an enzyme linked immunoabsorbant assay, following the manufacturer's guidelines (Ridgeway Science, Gloucestershire, UK). It was assumed that a concentration of $>1 \mathrm{ng} / \mathrm{mL}$ indicated the presence of an active CL. The limit of detection for the assay was $0.05 \mathrm{ng} / \mathrm{mL}$ and the intra- and inter-assay coefficients of variation were $2.7 \%$ and $12.2 \%$, respectively.

Once daily estradiol- $17 \beta$ concentrations were measured in peripheral plasma in duplicate, following diethyl ether extraction using the Estradiol MAIA radioimmunoassay kit (Serono Diagnostics Ltd; Woking, UK) as previously described (24). The limit of detection for the assay was $0.02 \mathrm{pg} / \mathrm{mL}$ and the inter- and intra-assay coefficients of variation were $20.8 \%$ and $21.6 \%$, respectively.

The concentrations of LH and FSH were measured in duplicate in peripheral plasma as described previously (25). Standards and iodinated tracers were purchased from the National Hormone and Pituitary Programme (NHPP, California, USA) and Amersham International PLC (Amersham, UK), respectively. The internal recovery was 95\% and the intra- and interassay coefficients of variation were $14.0 \%$ and $10.5 \%$ for FSH, and $14.0 \%$ and $10.4 \%$ for $\mathrm{LH}$, respectively.

Once daily concentrations of PGFM were measured in peripheral plasma samples by radioimmunoassay as previously described (26). Standards and tritiated tracers were purchased from Sigma Aldrich and Amersham, and the PGFM antibody used was generously donated by $\mathrm{H}$. Kindahl (Sweden). The limit of detection of the assay was $10 \mathrm{pg} /$ $\mathrm{mL}$, and the intra- and inter-assay coefficients of variation were 10.7 and $28.5 \%$, respectively.

The concentration of the acute phase protein $a_{1}$-acid glycoprotein (AGP) was measured using a biochemical assay as previously described (6). The limit of detection for the assay was $0.05 \mathrm{ng} / \mathrm{mL}$ and the intra- and inter-assay coefficients of variation were $12.0 \%$ and $18.0 \%$, respectively. 
Insulin-Growth Factor 1 (IGF-1) concentrations were measured in peripheral plasma collected on Day 0 and 9. Samples were assayed in duplicate using a single Immunoenzymometric kit according to the manufactures instructions (Immunodiagnostic systems; Tyne \& Wear, UK). The limit of detection for the assay was $1.9 \mu \mathrm{g} / \mathrm{L}$ and the intraassay coefficient of variation was $14.8 \%$.

\section{Statistical analysis}

Data were normalised to when estrus was first observed and Day 1 was defined as the first day of intra-uterine infusion. Values are presented as the arithmetic mean \pm SEM and significance was attributed when $\mathrm{P}<0.05$. Data from control and treated animals were compared by ANOVA and post hoc tests performed with Dunnets adjustment, except for proportions, which were compared using the Fisher exact test.

\section{Results}

\section{Endometrial tissue explants, epithelial and stromal cells}

The endometrial explants produced more PGE $(234.9 \pm 13.2$ vs. $33.9 \pm 13.8 \mathrm{ng} / \mathrm{mL}, \mathrm{P}<$ $0.001)$ and PGF $(14.6 \pm 1.4$ vs. $3.6 \pm 0.5 \mathrm{ng} / \mathrm{mL}, \mathrm{P}<0.001)$ in response to oxytocin and arachidonic acid than control tissues, confirming the tissues were physiologically functional in vitro. Stromal and epithelial cells have a polarised production of prostaglandin, producing predominantly PGE and PGF, respectively $(12,21)$. When treated with oxytocin and arachidonic acid, the stromal cells produced more PGE $(13.4 \pm 0.7$ vs. $0.7 \pm 0.3 \mathrm{ng} / \mathrm{mL}, \mathrm{P}<$ $0.05)$ and epithelial cells produced more PGF $(168.0 \pm 10.9$ vs. $4.5 \pm 0.4 \mathrm{ng} / \mathrm{mL}, \mathrm{P}<0.001)$ than controls, respectively. To ensure the growth medium for $A$. pyogenes did not stimulate prostaglandin production, the endometrial explants were treated with BHI. Addition of up to $28 \% \mathrm{BHI}$ in the explant media did not significantly affect the production of PGF $(4.5 \pm 1.6$ vs. $6.5 \pm 2.2 \mathrm{ng} / \mathrm{mL})$ or PGE ( $39.4 \pm 6.2$ vs. $42.4 \pm 5.1 \mathrm{ng} / \mathrm{mL})$ compared with controls.

The production of PGF from endometrial explants (Fig. 1a) or epithelial cells (Fig. 1b) treated with HKAP did not differ significantly from controls. Similarly, treatment with up to $10^{5}$ HKAP did not significantly affect the production of PGE, compared with controls, from the explants $(13.1 \pm 2.6$ vs. $9.3 \pm 1.6 \mathrm{ng} / \mathrm{ml})$ or stromal cells $(21.8 \pm 3.1$ vs. $17.5 \pm 2.6 \mathrm{ng} /$ $\mathrm{ml}$ ). However, endometrial explants treated with BFF produced more PGF (Fig. 2a) and PGE (Fig. 2b) than controls. Similarly, epithelial and stromal cells treated with BFF produced more PGF (Fig. 3a) and PGE (Fig. 3b) than controls, respectively. The endometrial explants, epithelial and stromal cells produced more prostaglandins in response to LPS (Fig. 2 and 3), which acted as a positive control in the present experiments to confirm the uterine tissues and cells were capable of responding to pathophysiological stimuli. In the light of the in vitro response to BFF but not HKAP, BFF was used for in vivo uterine infusion and the amount administered was based on the PGF and PGE response by the endometrial explants (Fig. 2).

\section{In vivo experiment}

The rectal temperatures of control and treated animals remained between $37.9-38.9{ }^{\circ} \mathrm{C}$ throughout the study and did not differ significantly between the treatment groups. Energy metabolism did not appear to be affected by BFF infusion as serum IGF-1 concentrations were similar for the control and treatment groups before (Day 0: $128.5 \pm 6.9$ vs. $129.9 \pm 4.8$ $\mathrm{ng} / \mathrm{mL}$ ) or after the infusions (Day 9: $131.7 \pm 10.36$ vs. $130.6 \pm 7.7 \mathrm{ng} / \mathrm{mL}$ ). Peripheral plasma PGFM concentrations did not differ between control and treatment groups before the first infusion was administered on Day 1 ( $20 \pm 4$ vs. $22 \pm 2 \mathrm{pg} / \mathrm{mL}$ ), Day 2 (20 44 vs. $17 \pm 4$ $\mathrm{pg} / \mathrm{mL}$ ) or on Day 3 ( $26 \pm 4$ vs. $18 \pm 2 \mathrm{pg} / \mathrm{mL}$ ). Similarly, plasma concentrations of $\mathrm{a}_{1}$-AGP 
did not differ significantly during the study between the control and treatment groups (1.35 \pm 0.35 vs. $1.05 \pm 0.18 \mathrm{ng} / \mathrm{mL}$ ).

The time to $\mathrm{LH}$ peak from $\mathrm{PG}_{2}$ was $61.3 \pm 4.1 \mathrm{~h}$ and the peak $\mathrm{LH}$ concentrations were similar for control and treated animals $(17.3 \pm 3.3$ vs. $15.8 \pm 3.1 \mathrm{ng} / \mathrm{mL})$. All animals ovulated after $\mathrm{PG}_{2}$ as determined by the expression of estrus behaviour, ovarian ultrasonograhpy and peripheral plasma progesterone concentrations $<1 \mathrm{ng} / \mathrm{ml}$ within 2 days. Following $\mathrm{PG}_{2}$ a new wave of follicles emerged in all animals and a dominant follicle was identified for each heifer. The diameter of the dominant follicle and peripheral plasma estradiol concentrations increased with time $(\mathrm{P}<0.05)$ but follicle growth and estradiol concentrations did not differ significantly between the control and treatment groups (Fig. 4a and b). Plasma FSH concentrations did not differ significant between the treatments groups (Fig 4c) and the LH concentration profiles were similar (Fig. 5). A new CL developed after $\mathrm{PG}_{2}$ in all animals and peripheral plasma progesterone concentrations (Fig. $4 \mathrm{~d}$ ) or the diameter of the CL did not differ significantly between the control and treated animals (21.1 \pm 0.6 vs. $18.1 \pm 1.4 \mathrm{~mm}$ at the time of $\mathrm{PG}_{3}$ ). Following $\mathrm{PG}_{3}$, maximal peripheral plasma $\mathrm{LH}$ concentrations did not differ significantly between control and treated animals (13.7 \pm 1.7 vs. $14.4 \pm 2.7 \mathrm{ng} / \mathrm{mL}$ ) and the time to $\mathrm{LH}$ peak was $51.6 \pm 4.4 \mathrm{~h}$. The proportion of animal ovulating did not differ between control and treated animals (6/7 vs. 5/7) and the maximum diameter of the ovulatory follicle did not differ significantly between the control and treated groups (13.7 \pm 0.8 vs. $14.8 \pm 1.0 \mathrm{~mm})$.

\section{Discussion}

After parturition, infection of the uterus with $A$. pyogenes and E. coli is associated with clinical endometritis and infertility, and ovarian follicle growth and function are perturbed $(1,27)$. Endometrial explants or cells produce PGE and PGF when treated with heat-killed $E$. coli or LPS (12). In the present study, treatment of endometrial explants or uterine epithelial and stromal cells with heat-killed $A$. pyogenes did not stimulate prostaglandin production. However, a bacteria-free filtrate (BFF) cultivated from $A$. pyogenes stimulated PGE and PGF production from endometrial explants, and from stromal and epithelial cells. These observations support the concept that the bacteria secrete a heat-labile toxin rather than interacting directly with host cells $(28,29)$. However, when the same BFF was infused into the uterus of heifers there was no evidence of an effect on the immune response, as determined by acute phase protein or PGFM concentrations or rectal temperature, and there was no effect on their reproductive biology.

The cow provides a convenient model to study uterine disease because endometrium is readily available and pure populations of endometrial cells can be obtained (30). In the present study, the endometrial explants produced PGF and PGE in response to oxytocin and arachidonic acid, and the stromal and epithelial cells produced predominantly PGE and PGF, respectively, supporting previous observations $(12,21)$. The explants and cells also produced prostaglandins in response to E. coli LPS, as reported previously (12). Thus, the uterine tissues and cells in the present study were capable of functional physiological and patho-physiological responses.

Heat killed $A$. pyogenes did not stimulate a prostaglandin response by the endometrial explants, epithelial or stromal cells. This is in marked contrast to the other major uterine pathogen, E. coli, where similar concentrations of heat killed bacteria stimulate substantial prostaglandin production and increased expression of gene transcripts for cytokines associated with inflammation (12). The explanation for the difference between the bacteria is likely to be that $E$. coli express LPS on their surface after heat-killing, which is highly immunogenic (31,32). In contrast, $A$. pyogenes appear to secrete a heat-labile haemolytic 
exotoxin that is associated with tissue damage $(28,29)$. Secretion of this exotoxin likely requires live bacteria or bacteria killed by a different method than heat and so a BFF was prepared from cultured $A$. pyogenes. Treatment of the endometrial explants or cells with BFF stimulated the production of PGE and PGF. This observation supports the concept that A. pyogenes exotoxin is likely to be more important during clinical uterine disease than direct interactions with the bacteria and so the effect of BFF was tested in the whole animal.

In the whole animal, infusion of E. coli or LPS into the uterus or peripheral blood perturbs ovarian follicular growth, ovulation, estradiol and LH secretion $(13,14,33)$. The effects of $A$. pyogenes are less clear but infusion of BFF into the uterus provokes an influx of neutrophils into the uterine lumen $(18,34)$. Furthermore, there was embryo mortality after uterine infusion of similar numbers of live $A$. pyogenes to the number of bacteria in the culture from which the BFF was derived (35). However in the present study, infusion of BFF into the uterine lumen of the heifers did not affect ovarian events, hormone concentrations, or markers of an inflammatory response such as PGFM and acute phase proteins. This might be because there was an insufficient concentration of toxin in the BFF, compared with that generated by live bacteria. Alternatively, heifers may be more resilient to uterine inflammation than postpartum cows, where the endometrium is already traumatised and there is lochia in which bacteria can readily proliferate, which would facilitate the growth and colonisation of $A$. pyogenes. Indeed, in cattle and sheep it was necessary to traumatise the endometrium to cause inflammation or establish experimental infections $(36,37)$.

In conclusion, endometrial explants and purified populations of epithelial or stromal cells produced prostaglandins in response to BFF cultured from $A$. pyogenes, but not heat-killed bacteria. However, intrauterine infusion of BFF did not influence ovarian or endocrine events in heifers. In the live animal it is likely that the intact uterine mucosa is more resistant to the soluble exotoxin of $A$. pyogenes than explants or cells in vitro.

\section{Acknowledgments}

This work was supported by grants from the Wellcome Trust (064155) and BBSRC (S19795).

\section{References}

1. Sheldon IM, Lewis GS, LeBlanc SJ, Gilbert RO. Defining postpartum uterine disease in cattle. Theriogenology. 2006; 65:1516-1530. [PubMed: 16226305]

2. Sheldon IM, Noakes DE, Rycroft AN, Pfeiffer DU, Dobson H. Influence of uterine bacterial contamination after parturition on ovarian dominant follicle selection and follicle growth and function in cattle. Reproduction. 2002; 123:837-845. [PubMed: 12052238]

3. Borsberry S, Dobson H. Periparturient diseases and their effect on reproductive performance in five dairy herds. Veterinary Record. 1989; 124:217-219. [PubMed: 2929110]

4. LeBlanc SJ, Duffield TF, Leslie KE, Bateman KG, Keefe GP, Walton JS, Johnson WH. Defining and diagnosing postpartum clinical endometritis and its impact on reproductive performance in dairy cows. Journal of Dairy Science. 2002; 85:2223-2236. [PubMed: 12362455]

5. McDougall S. Effect of intrauterine antibiotic treatment on reproductive performance of dairy cows following periparturient disease. New Zealand Veterinary Journal. 2001; 49:150-158. [PubMed: 16032183]

6. Sheldon IM, Noakes DE, Rycroft A, Dobson H. Acute phase protein response to postpartum uterine bacterial contamination in cattle. Veterinary Record. 2001; 148:172-175. [PubMed: 11258722]

7. Lindell J-O, Kindahl H, Jansson L, Edqvist L-E. Post-partum release of prostaglandin F2a and uterine involution in the cow. Theriogenology. 1982; 17:237-243. [PubMed: 16725686]

8. Del Vecchio RP, Matsas DJ, Inzana TJ, Sponenberg DP, Lewis GS. Effect of intrauterine bacterial infusions and subsequent endometritis on prostaglandin $\mathrm{F}_{2 a}$ metabolite concentrations in postpartum beef cows. Journal of Animal Science. 1992; 70:3158-3162. [PubMed: 1429292] 
9. Gilbert RO, Shin ST, Guard CL, Erb HN, Frajblat M. Prevalence of endometritis and its effects on reproductive performance of dairy cows. Theriogenology. 2005; 64:1879-1888. [PubMed: 15961149]

10. Bonnett BN, Martin SW, Gannon VP, Miller RB, Etherington WG. Endometrial biopsy in Holstein-Friesian dairy cows. III. Bacteriological analysis and correlations with histological findings. Canadian Journal of Veterinary Research. 1991; 55:168-173. [PubMed: 1884297]

11. Opsomer G, Grohn YT, Hertl J, Coryn M, Deluyker H, de Kruif A. Risk factors for post partum ovarian dysfunction in high producing dairy cows in Belgium: a field study. Theriogenology. 2000; 53:841-857. [PubMed: 10730974]

12. Herath S, Fischer DP, Werling D, Williams EJ, Lilly ST, Dobson H, Bryant CE, Sheldon IM. Expression and function of Toll-like receptor 4 in the endometrial cells of the uterus. Endocrinology. 2006; 147:562-570. [PubMed: 16223858]

13. Peter AT, Bosu WTK, DeDecker RJ. Suppression of preovulatory luteinizing hormone surges in heifers after intrauterine infusions of Escherichia coli endotoxin. American Journal of Veterinary Research. 1989; 50:368-373. [PubMed: 2648904]

14. Karsch FJ, Battaglia DF, Breen KM, Debus N, Harris TG. Mechanisms for ovarian cycle disruption by immune/inflammatory stress. Stress. 2002; 5:101-112. [PubMed: 12186688]

15. Griffin JFT, Hartigan PJ, Nunn WR. Non-specific uterine infection and bovine fertility. I. Infection patterns and endometritis during the first seven weeks post-partum. Theriogenology. 1974; 1:91106. [PubMed: 4619812]

16. Williams EJ, Fischer DP, England GCW, Dobson H, Pfeiffer DU, Sheldon IM. Clinical evaluation of postpartum vaginal mucus reflects uterine bacterial infection and the inflammatory response to endometritis in cattle. Theriogenology. 2005; 63:102-117. [PubMed: 15589277]

17. Jost BH, Billington SJ. Arcanobacterium pyogenes: molecular pathogenesis of an animal opportunist. Antonie Van Leeuwenhoek. 2005; 88:87-102. [PubMed: 16096685]

18. Subandrio AL, Sheldon IM, Noakes DE. Peripheral and intrauterine neutrophil function in the cow: the influence of endogenous and exogenous sex steroid hormones. Theriogenology. 2000; 53:1591-1608. [PubMed: 10883846]

19. Ireland JJ, Murphee RL, Coulson PB. Accuracy of predicting stages of bovine estrous cycle by gross appearance of the corpus luteum. Journal of Dairy Science. 1980; 63:155-160. [PubMed: 7372895]

20. Lewis GS. Steroidal regulation of uterine immune defenses. Animal Reproduction Science. 2004; 82-83:281-294. [PubMed: 15271460]

21. Asselin E, Goff AK, Bergeron H, Fortier MA. Influence of sex steroids on the production of prostaglandins F2 alpha and E2 and response to oxytocin in cultured epithelial and stromal cells of the bovine endometrium. Biology of Reproduction. 1996; 54:371-379. [PubMed: 8788188]

22. Cheng Z, Robinson RS, Pushpakumara PG, Mansbridge RJ, Wathes DC. Effect of dietary polyunsaturated fatty acids on uterine prostaglandin synthesis in the cow. Journal of Endocrinology. 2001; 171:463-473. [PubMed: 11739012]

23. Poyser NL. Effects of various factors on prostaglandin synthesis by the guinea-pig uterus. Journal of Reproduction \& Fertility. 1987; 81:269-276. [PubMed: 3118014]

24. Prendiville DJ, Enright WJ, Crowe MA, Finnerty M, Hynes N, Roche JF. Immunization of heifers against gonadotropin-releasing hormone: antibody titers, ovarian function, body growth, and carcass characteristics. Journal of Animal Science. 1995; 73:2382-2389. [PubMed: 8567476]

25. Dobson H, Ribadu AY, Noble KM, Tebble JE, Ward WR. Ultrasonography and hormone profiles of adrenocorticotrophic hormone (ACTH)-induced persistent ovarian follicles (cysts) in cattle. Journal of Reproduction and Fertility. 2000; 120:405-410. [PubMed: 11058457]

26. Kindahl H, Edqvist L-E, Granstrom E, Bane A. The release of Prostaglandin $F_{2 a}$ as reflected by 15-keto-13,14-dihydroprostaglandin $\mathrm{F}_{2 a}$ in the peripheral circulation during normal luteolysis in heifers. Prostaglandins. 1976; 11:871-878. [PubMed: 945590]

27. Sheldon IM, Dobson H. Postpartum uterine health in cattle. Animal Reproduction Science. 2004; 82-83:295-306. [PubMed: 15271461] 
28. Funk PG, Staats JJ, Howe M, Nagaraja TG, Chengappa MM. Identification and partial characterization of an Actinomyces pyogenes hemolysin. Veterinary Microbiology. 1996; 50:129142. [PubMed: 8810014]

29. Billington SJ, Jost BH, Cuevas WA, Bright KR, Songer JG. The Arcanobacterium (Actinomyces) pyogenes hemolysin, pyolysin, is a novel member of the thiol-activated cytolysin family. Journal of Bacteriology. 1997; 179:6100-6106. [PubMed: 9324258]

30. Herath S, Dobson H, Bryant CE, Sheldon IM. Use of the cow as a large animal model of uterine infection and immunity. Journal of Reproductive Immunology. 2006; 69:13-22. [PubMed: 16386311]

31. Beutler B, Hoebe K, Du X, Ulevitch RJ. How we detect microbes and respond to them: the Tolllike receptors and their transducers. Journal of Leukocyte Biology. 2003; 74:479-485. [PubMed: 12960260]

32. Akira S, Uematsu S, Takeuchi O. Pathogen recognition and innate immunity. Cell. 2006; 124:783801. [PubMed: 16497588]

33. Suzuki C, Yoshioka K, Iwamura S, Hirose H. Endotoxin induces delayed ovulation following endocrine aberration during the proestrous phase in Holstein heifers. Domestic Animal Endocrinology. 2001; 20:267-278. [PubMed: 11518620]

34. Subandrio AL, Noakes DE. Neutrophil migration into the uterine lumen of the cow: the influence of endogenous and exogenous sex steroid hormones using two intrauterine chemoattractants. Theriogenology. 1997; 47:825-835. [PubMed: 16728032]

35. Semambo DK, Ayliffe TR, Boyd JS, Taylor DJ. Early abortion in cattle induced by experimental intrauterine infection with pure cultures of Actinomyces pyogenes. Veterinary Record. 1991; 129:12-16. [PubMed: 1897106]

36. Ayliffe TR, Noakes DE. Effects of exogenous oestrogen and experimentally induced endometritis on absorption of sodium benzylpenicillin from the cow's uterus. Veterinary Record. 1982; 110:9698. [PubMed: 7186696]

37. Regassa, Sheldon I, Noakes DE. Effect of experimentally induced metritis on uterine involution, acute phase protein response and PGFM secretion in the postpartum ewe. Veterinary Record. 2002; 150:605-607. [PubMed: 12036244] 

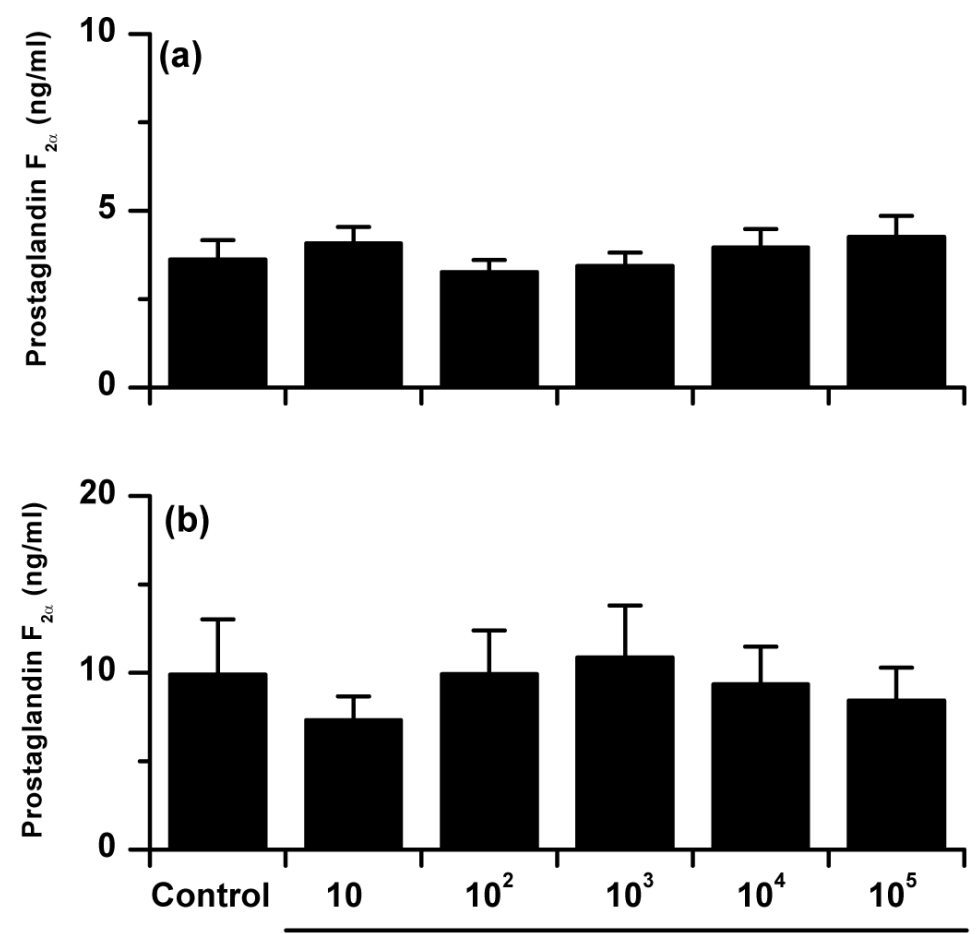

HKAP (per ml)

Figure 1.

The mean + SEM production of prostaglandin $\mathrm{F}_{2}$ by endometrial (a) explants, and (b) epithelial cells treated with heat killed $A$. pyogenes (HKAP) at the concentrations indicated for $24 \mathrm{~h}$. 

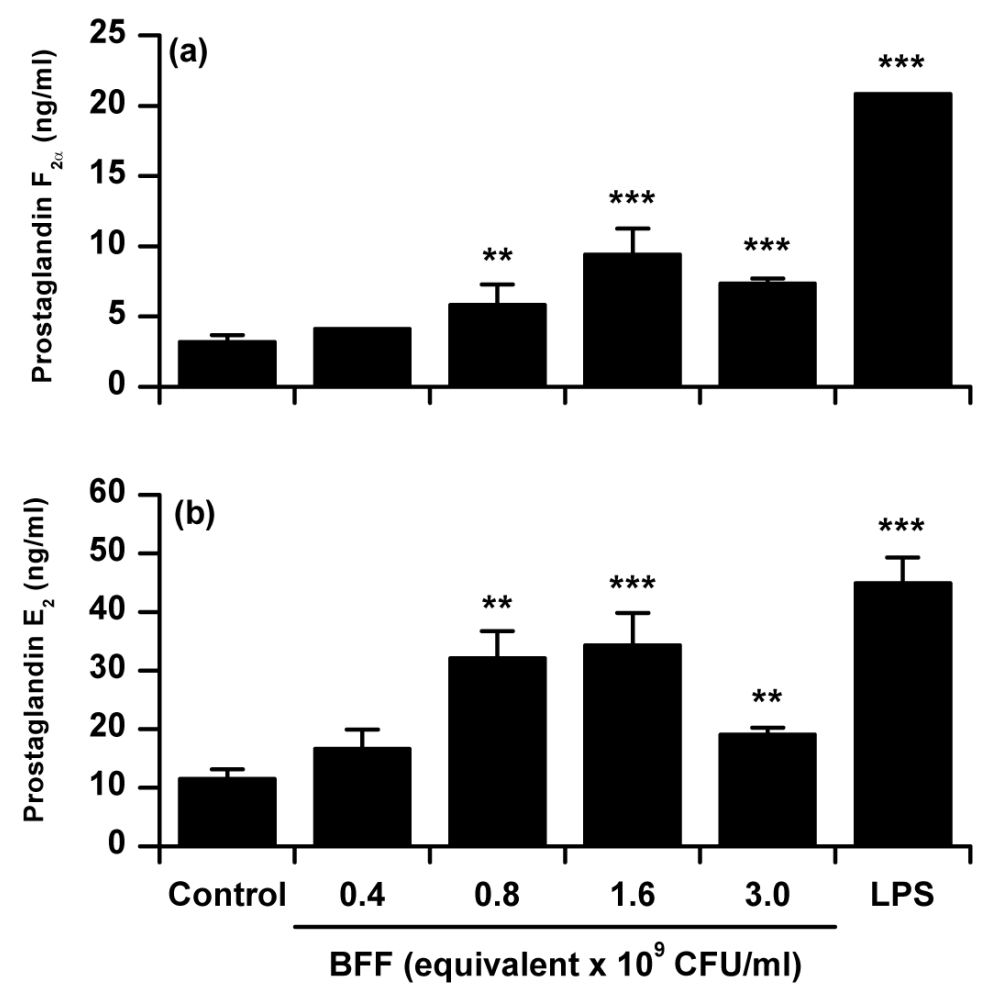

Figure 2.

The mean + SEM production of (a) prostaglandin $\mathrm{F}_{2 a}$ and (b) prostaglandin $\mathrm{E}_{2}$, by tissue explants treated for $24 \mathrm{~h}$ with BFF at the concentrations indicated or $1 \mu \mathrm{g} / \mathrm{mL} \mathrm{E}$. coli LPS. Values differ significantly from control $* * * \mathrm{P}<0.01, * * \mathrm{P}<0.05$ 

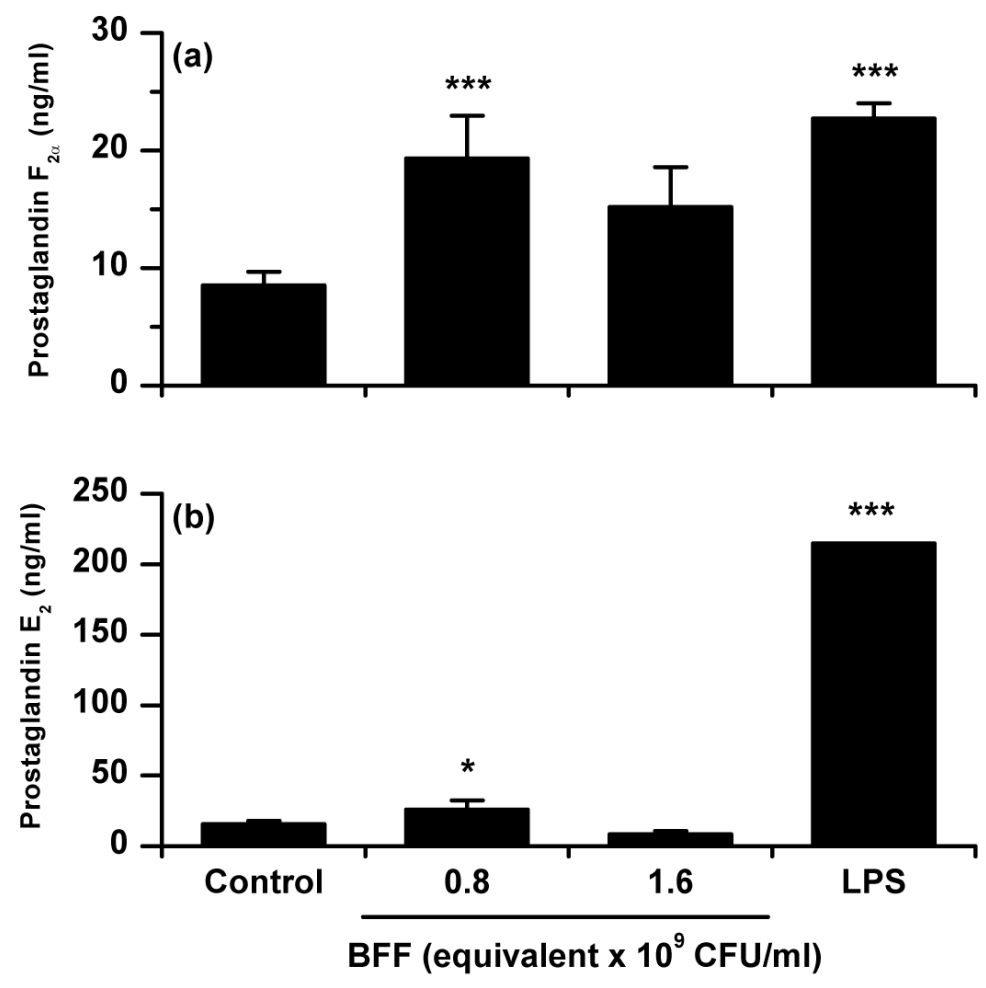

Figure 3.

The mean + SEM production of (a) prostaglandin $\mathrm{F}_{2}$ by endometrial epithelial cells, and (b) prostaglandin $\mathrm{E}_{2}$ by stromal cells treated with $\mathrm{BFF}$ at the concentrations indicated or $1 \mu \mathrm{g} /$ $\mathrm{mL}$ E. coli LPS. Values differ significantly from control $* * * \mathrm{P}<0.01, * \mathrm{P}<0.05$ 

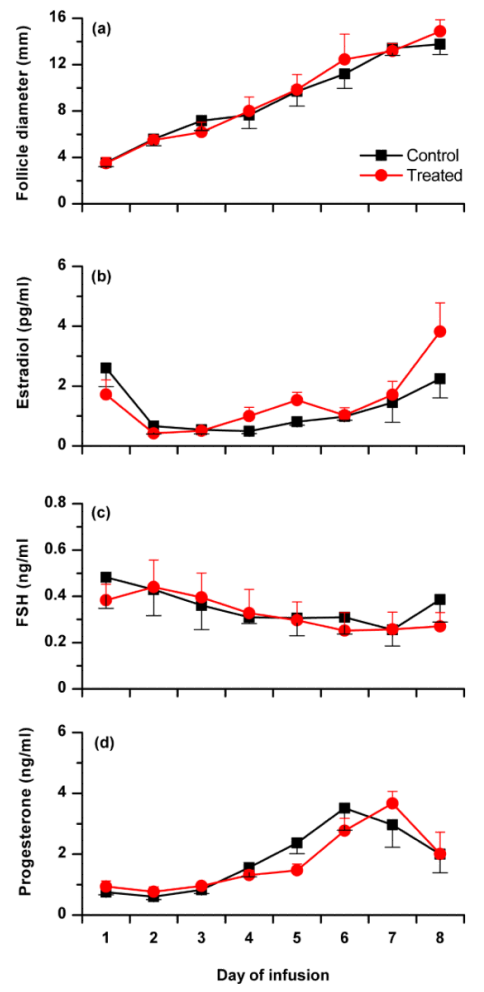

Figure 4.

The mean \pm SEM (a) diameter of the dominant follicle and peripheral plasma concentrations of (b) estradiol, (c) FSH, and (d) progesterone, for of 7 heifers infused with control PBS ( $\square$ ) or $\mathrm{BFF}(\mathbf{)})$ for 8 days. 

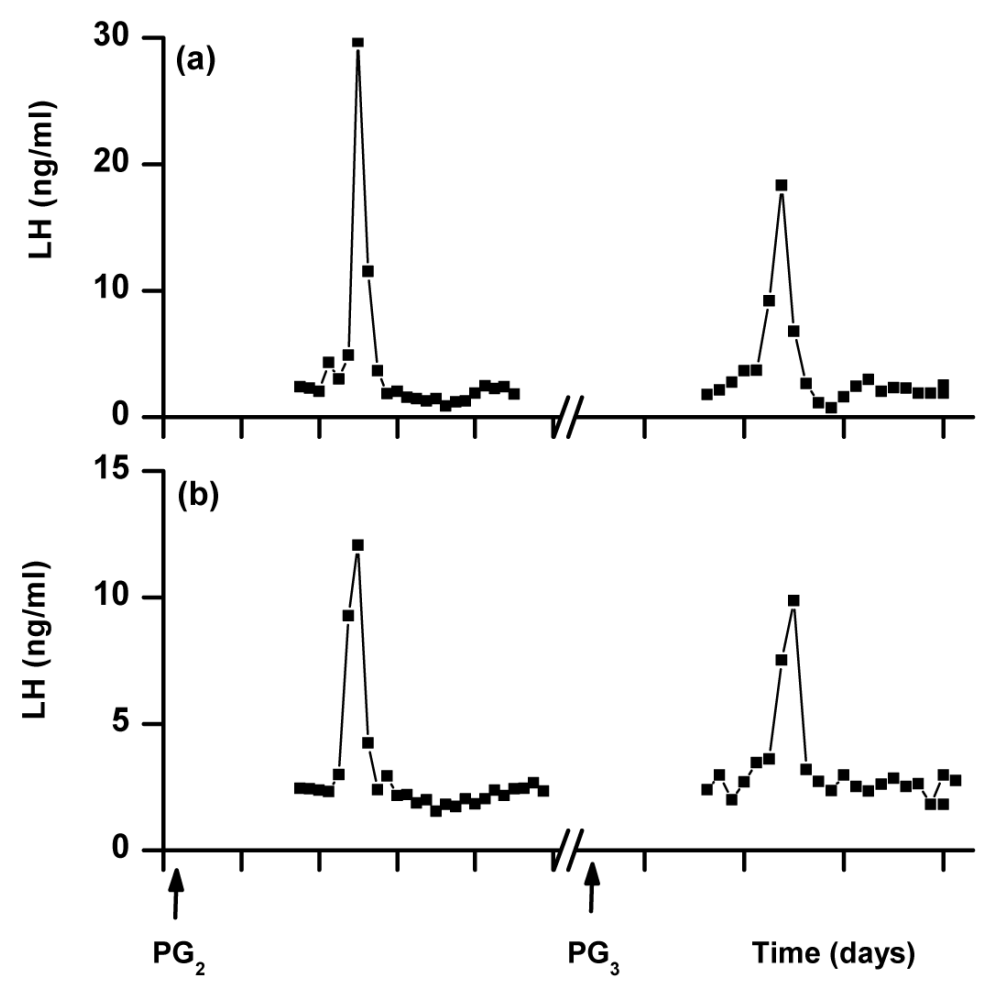

Figure 5.

Representative peripheral plasma $\mathrm{LH}$ concentration profiles after $\mathrm{PG}_{2}$ and $\mathrm{PG}_{3}$ for animals that were infused with (a) control PBS, or (b) BFF. 